\title{
Simultaneous removal of acidity and lead from acid lead battery wastewater by aluminum and iron electrocoagulation
}

\author{
K. Dermentzis ${ }^{1, *}$, E. Valsamidou ${ }^{2}$, D. Marmanis ${ }^{2}$ \\ ${ }^{1}$ Dpt. of Engineering Science, Laboratory of Chemical Technology and Electrochemistry, Kavala Institute of Technology, 65404 Saint \\ Loucas, Kavala, Greece. \\ ${ }^{2}$ Dpt. of Petroleum and Natural Gas Technology, Laboratory of Environmental Protection, Kavala Institute of Technology, 65404 Saint \\ Loucas, Kavala, Greece.
}

Received 2 September 2011; Accepted 25 August 2012

\begin{abstract}
In this work the performance of electrocoagulation in the treatment of acid lead battery manufacturing wastewater was studied. Both iron and aluminum sacrificial electrodes remove lead effectively. However, $\mathrm{pH}$ of the treated wastewater depends on the electrode material and the supporting electrolyte used. Iron electrocoagulation with $\mathrm{KCl}$ as supporting electrolyte reduces the initial $\mathrm{Pb}^{2+}$ ion concentration of $8.6 \mathrm{mg} \mathrm{L}^{-1}$ to $0.2 \mathrm{mg} \mathrm{L}^{-1}$ in 20 minutes of electrolysis time. At the same time, however, the initial wastewater $\mathrm{pH}$ of 2.96 rises sharply to 12.24 exceeding by far the upper legal limit for effluent discharge to the environment. On the contrary iron electrocoagulation with $\mathrm{Na}_{2} \mathrm{SO}_{4}$ as supporting electrolyte does not increase $\mathrm{pH}$ sufficiently to the appropriate range. Aluminum treatment with $\mathrm{KCl}$ and $\mathrm{Na}_{2} \mathrm{SO}_{4}$ electrolytes need 35 minutes of electrolysis time for effective lead removal. Effective removal of both, acidity and lead in a single step was achieved in only 25 minutes of electrolysis time with iron electrodes and a mixed supporting electrolyte solution containing $0.03 \mathrm{M} \mathrm{Na}_{2} \mathrm{SO}_{4}$ and $0.003 \mathrm{M} \mathrm{KCl}$.
\end{abstract}

Keywords: Acid lead battery wastewater, aluminum and iron sacrificial electrodes, electrochemical coagulation.

\section{Introduction}

Heavy metal pollution has become in the last decades an increasing environmental problem worldwide. Heavy metals are discharged from various industries, such as mining, metal refineries, smelters, electroplating and textile. Even at low concentrations these metals are toxic to organisms and humans. Lead has long been recognized as one of the three most toxic heavy metals (mercury, lead, cadmium). Therefore, increasing pressure is being placed on industries to reduce their lead wastes. The maximum allowable concentration of lead is $0.05 \mathrm{mg} \mathrm{L}^{-1}$ for drinking water and $0.2 \mathrm{mg} \mathrm{L}^{-1}$ for effluent discharge. Lead is used for manufacturing of storage batteries, due to its characteristic properties: conductivity, corrosion resistance and reversibility of the reaction between lead, lead oxide and sulfuric acid.

Wastewater from acid lead battery manufacturing or recycling industries contains mainly $\mathrm{H}_{2} \mathrm{SO}_{4}$ at a $\mathrm{pH}$ of $1.2-3$ and soluble $\mathrm{Pb}^{2+}$ ions at a concentration of $5-15 \mathrm{mg} \mathrm{L}^{-1}$.

Neutralization with alkaline substances, such as sodium hydroxide, sodium carbonate, lime or dolomite can adjust $\mathrm{pH}$ in the appropriate range $(5.5$ - 9.). This operation, however, cannot effectively reduce the $\mathrm{Pb}$ concentration, because the formed $\mathrm{Pb}(\mathrm{OH})_{2}$ is moderately soluble. To

\footnotetext{
* E-mail address: demerz@otenet.gr

ISSN: 1791-2377 @ 2012 Kavala Institute of Technology. All rights reserved.
}

achieve $\mathrm{Pb}$ concentrations under the permissible limits a second sulfide or phosphate precipitation or ion exchange is needed. A mixed precipitation/coagulation process based on $\mathrm{Fe}(\mathrm{OH})_{3}$ co-precipitation has been reported by Macchi et al. [1]. When lead ions are removed by ion exchange it is difficult to elude them from the resin by regeneration requiring the disposal of the spent resin. Removal of lead and other heavy metals by biosorption [2], absorption on zeoliths [3] membrane electrodialysis [4] and membrane-less electrostatic shielding electrodialysis $[5,6]$, has also been reported.

Chemical coagulation is a quite effective method for treating heavy metal bearing wastewaters but may induce secondary pollution by adding coagulants, such as aluminum or iron salts or organic poly-electrolytes to remove colloidal matter as gelatinous hydroxides. This wastewater treatment process produces large amounts of sludge.

Electrocoagulation uses no chemicals as coagulating agents. These are generated during the electrolysis process by electro-dissolution of a sacrificial anode made of aluminum or iron. Electrocoagulation has been successfully performed for decolorization treatment of dyes and remediation of dye-house wastewaters $[7,8]$, treatment of oil wastes $[9,10]$, diary effluents [11], diesel and bio-diesel wastewaters [12,13], laundry wastewaters (14], slaughter house effluents [15], arsenic or fluoride containing waters $[16,17]$ and heavy metal bearing effluents [18-21].

In spite of abundant applications of electrocoagulation for the treatment of various kinds of wastewater, its use for the treatment of acid lead battery wastewater is scarce in 
literature [22]. The present work reports the efficiency of electrocoagulation in simultaneously removing both, lead and acidity from battery wastewater in a single operation using electrocoagulation with aluminum and iron electrodes.

\section{Materials and Methods}

\subsection{Chemicals}

$\mathrm{KCl}, \mathrm{Na}_{2} \mathrm{SO}_{4}, \mathrm{H}_{2} \mathrm{SO}_{4}$ and $\mathrm{KOH}$ were of analytical grade (Merck).

The wastewater sample was obtained from a battery manufacturing unit located near Thessaloniki, northern Greece. Its main characteristics are shown in Table 1.

\subsection{Apparatus}

A laboratory model DC power supply apparatus (PHYWE Systeme GmbH \& Co. KG. Germany) was used to maintain constant DC current. Voltage and current were measured by a multimeter (PHYWE). Conductivity was measured by means of a conductometer (inoLab Cond. Level 1, WTW). The $\mathrm{pH}$ and the temperature were measured using a Hanna (HI8314) $\mathrm{pH}$-meter connected to a combined electrode comprising a temperature sensor (HI1217D).

Electrolyses were conducted at room temperature in a cylindrical glass cell of $400 \mathrm{ml}$ in which aliquot solutions of $250 \mathrm{ml}$ were placed and slowly stirred with a magnetic bar at $500 \mathrm{rpm}$. A pair of commercially obtained aluminum or iron plates of size $10 \mathrm{~cm} \times 5 \mathrm{~cm} \times 0.5 \mathrm{~cm}$ immersed to a $6 \mathrm{~cm}$ depth with an effective area of $30 \mathrm{~cm}^{2}$ each were used as electrodes in the experiments. The inter-electrode distance was $1.5 \mathrm{~cm}$. To remove the oxide and passivation layer from aluminium and iron surface the electrodes were grinded with sandpaper and energized by dipping them in $5 \mathrm{~N} \mathrm{HCl}$ for 1 minute. $0.03 \mathrm{M} \mathrm{KCl}, 0.03 \mathrm{M} \mathrm{Na}_{2} \mathrm{SO}_{4}$ or a mixed solution containing $0.03 \mathrm{M} \mathrm{Na}_{2} \mathrm{SO}_{4}$ and $0.003 \mathrm{M} \mathrm{KCl}$ respectively was used as supporting electrolytes. The polarity of the cell was reversed every 20 minutes to limit the formation of the passivation layers on the electrodes.

Samples were extracted every 5 minutes and filtered using Whatman filter paper (Grade 40). The residual $\mathrm{Pb}$ concentrations were determined by Atomic Absorption Spectroscopy AAS (Perkin Elmer 5100). At the end of each experiment the produced sludge and the mass loss of the aluminum electrodes were measured.

Table 1. Main characteristics of wastewater.

\begin{tabular}{lc}
\hline Parameter & Value \\
\hline $\mathrm{pH}$ & 2.96 \\
$\mathrm{~Pb}\left(\mathrm{mg} \mathrm{L}^{-1}\right)$ & 8.6 \\
$\mathrm{SO}_{4}\left(\mathrm{mg} \mathrm{L}^{-1}\right)$ & 280 \\
$\mathrm{Ca}\left(\mathrm{mg} \mathrm{L}^{-1}\right)$ & 76 \\
$\mathrm{Mg}\left(\mathrm{mg} \mathrm{L}^{-1}\right)$ & 12 \\
\hline
\end{tabular}

\subsection{Brief description of electrocoagulation}

Electrocoagulation is a process consisting of creating metallic hydroxide flocks inside the wastewater by electrodissolution of soluble anodes made of aluminium or iron. The main reactions occurring during electrocoagulation produce aluminium ions at the sacrificial anode and hydroxide ions as well hydrogen gas at the cathode:

$$
\begin{aligned}
& \mathrm{Al} \rightarrow \mathrm{Al}^{3+}+3 \mathrm{e}^{-} \text {(anode) } \\
& 2 \mathrm{H}_{2} \mathrm{O}+2 \mathrm{e}^{-} \rightarrow 2 \mathrm{OH}^{-}+\mathrm{H}_{2} \text { (cathode) }
\end{aligned}
$$

The generated $\mathrm{Al}^{3+}$ and $\mathrm{OH}^{-}$ions react to form various monomeric and polymeric species such as $\mathrm{Al}(\mathrm{OH})^{2+}$, $\mathrm{Al}(\mathrm{OH})_{2}{ }^{+}, \mathrm{Al}_{2}(\mathrm{OH})_{2}{ }^{4+}, \mathrm{Al}(\mathrm{OH})^{4-}, \mathrm{Al}_{6}(\mathrm{OH})_{15}{ }^{3+}, \mathrm{Al}_{7}(\mathrm{OH})_{17}{ }^{4+}$, $\mathrm{Al}_{8}(\mathrm{OH})_{20}{ }^{7+}, \quad \mathrm{Al}_{13} \mathrm{O}_{4}(\mathrm{OH})_{24}{ }^{7+}, \mathrm{Al}_{13}(\mathrm{OH})_{34}{ }^{5+}$ which finally result in situ formation of gelatinous $\mathrm{Al}(\mathrm{OH})_{3}$ effecting the coagulation and co-precipitation of particulates from the solution by adsorption as described by Kobya et al. [7]. The liberated $\mathrm{H}_{2}$ gas at the cathode can remove dissolved organics or any suspended material by flotation. The aluminum hydroxide flocks act as absorbents for heavy metal ions. Furthermore, heavy metal ions combine with the electro-generated $\mathrm{OH}^{-}$ions at the cathode and precipitate in form of their insoluble hydroxides. Both phenomena act synergistically leading to a rapid removal of heavy metal pollutants from water.

In case sacrificial iron anodes are used reaction (3) occurs at the anode:

$\mathrm{Fe} \rightarrow \mathrm{Fe}^{3+}+3 \mathrm{e}^{-}$(anode)

The generated $\mathrm{Fe}^{3+}$ ions undergo hydration and give, depending on $\mathrm{pH}$, cationic species such as $\mathrm{Fe}(\mathrm{OH})^{2+}$, $\mathrm{Fe}(\mathrm{OH})_{2}{ }^{2+}$ in acidic conditions, neutral $\mathrm{Fe}(\mathrm{OH})_{3}$ in neutral conditions and anionic species such as $\mathrm{Fe}(\mathrm{OH})_{4}^{-}, \mathrm{Fe}(\mathrm{OH})_{6}{ }^{3-}$ in alkaline conditions which finally result in situ formation of gelatinous $\mathrm{Fe}(\mathrm{OH})_{3}$ effecting the coagulation and coprecipitation from the solution by adsorption. The iron hydroxide flocks act as absorbents for heavy metal ions. $\mathrm{Fe}^{3+}$ as a flocculation agent is advantageous, due to its innocuity compared to $\mathrm{Al}^{3+}$, which shows some toxic effects.

\section{Results and Discussion}

\subsection{Treatment with $\mathrm{KCl}$ as supporting electrolyte}

It is well known that, during the electro-coagulation process, heavy metals are removed by absorption on the electrolytically produced $\mathrm{Fe}(\mathrm{OH})_{3}$ or $\mathrm{Al}(\mathrm{OH})_{3}$ flocks and by precipitation in form of their insoluble hydroxides. Furthermore, $\mathrm{pH}$ increases, due to hydrogen formation at the cathode. We can take advantage of these phenomena and drive in a single step both, lead concentration reduction under its permissible limit $\left(0.2 \mathrm{mg} \mathrm{L}^{-1}\right)$ and $\mathrm{pH}$ elevation to the appropriate range $(5.5-9)$. To achieve this, the acid lead battery wastewater was treated electrochemically with iron and aluminum sacrificial electrodes and supporting electrolytes, such as $\mathrm{KCl}, \mathrm{Na}_{2} \mathrm{SO}_{4}$ and a combination of them.

As can be obtained from Fig. 1a the initial $\mathrm{Pb}$ concentration of $8.6 \mathrm{mg} \mathrm{L}^{-1}$ falls under the permissible limit in only 20 minutes of electrolysis time with iron electrodes at a current density of $10 \mathrm{~mA} \mathrm{~cm}{ }^{2} . \mathrm{pH}$, however, increases sharply to 12.24 exceeding by far the legal limit. When aluminum electrodes are used (Fig. 1b) the reduction of $\mathrm{Pb}$ concentration to the legal limit is somehow slower taking 35 minutes whereas $\mathrm{pH}$ rises slightly over 9 . 


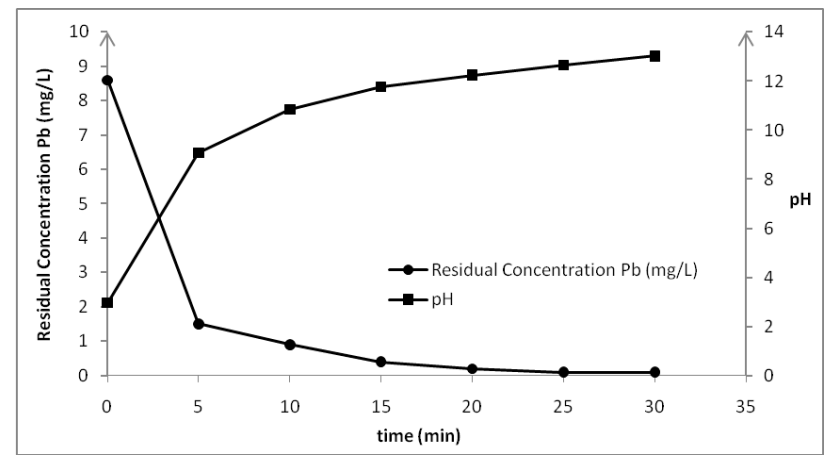

(a)

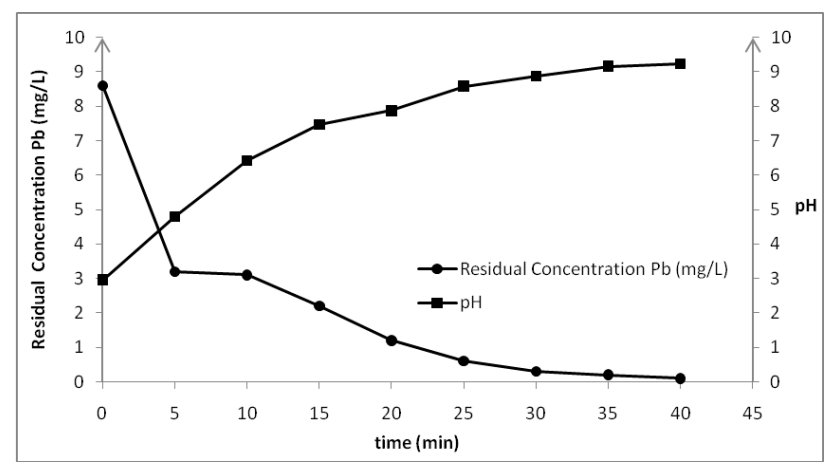

(b)

Fig. 1. Residual $\mathrm{Pb}^{2+}$ ion concentration and $\mathrm{pH}$ variation versus time during electrocoagulation of acid battery wastewater with a) iron electrodes and $\mathrm{b}$ ) aluminum electrodes. (supporting electrolyte $\mathrm{KCl} 0.03$ $\mathrm{M}$, solution volume $\mathrm{V}=250 \mathrm{ml}$, current density $\mathrm{i}=10 \mathrm{~mA} \mathrm{~cm}$ ).

Other reactions taking place at the electrodes beyond (1), (2) and (3) are:

$$
\begin{aligned}
& 2 \mathrm{OH}^{-} \rightarrow \mathrm{O}_{2}+\mathrm{H}_{2} \mathrm{O}+2 \mathrm{e} \text { anode } \\
& 2 \mathrm{Cl}^{-} \rightarrow \mathrm{Cl}_{2}+2 \mathrm{e} \text { anode } \\
& \mathrm{Fe} \rightarrow \mathrm{Fe}^{2+}+2 \mathrm{e} \text { cathode }
\end{aligned}
$$

Furthermore, the anodically formed $\mathrm{Fe}^{2+}, \mathrm{Fe}^{3+}$ and $\mathrm{Al}^{3+}$ ions combine with the cathodically generated $\mathrm{OH}^{-}$ions forming their insoluble hydroxides:

$$
\begin{aligned}
& \mathrm{Fe}^{2+}+2 \mathrm{OH}^{-} \rightarrow \mathrm{Fe}(\mathrm{OH})_{2} \\
& \mathrm{Fe}^{3+}+3 \mathrm{OH}^{-} \rightarrow \mathrm{Fe}(\mathrm{OH})_{3} \\
& \mathrm{Al}^{3+}+3 \mathrm{OH}^{-} \rightarrow \mathrm{Al}(\mathrm{OH})_{3}
\end{aligned}
$$

The value of $\mathrm{pH}$ rises more sharply when Fe-electrodes are used. Iron has a higher electrochemical potential and therefore higher stability than aluminium. It means that the partial reaction (5) occurs to some extent on cost of reactions (3), (4) and (6). Reaction (5) is more favoured at the more electropositive $\mathrm{Fe}$ than at the $\mathrm{Al}$ anode. Furthermore, due to considerable difference in solubility between $\mathrm{Fe}(\mathrm{OH})_{2}$ and $\mathrm{Al}(\mathrm{OH})_{3}$, the cathodically generated $\mathrm{OH}^{-}$ions are preferentially bound to $\mathrm{Al}^{3+}$ than to $\mathrm{Fe}^{2+}$ ions. Consequently, a larger excess of $\mathrm{OH}^{-}$ions and a $\mathrm{pH}$ increase in the treated solution is observed in case of iron than of aluminium electrocoagulation.

\subsection{Treatment with $\mathrm{Na}_{2} \mathrm{SO}_{4}$ as supporting electrolyte}

In absence of $\mathrm{Cl}^{-}$ions and their anodic oxidation reaction (5), $\mathrm{pH}$ should not increase sharply, as stated in section 3.1. Fig. 2a shows the electrocoagulation treatment of the battery wastewater with $\mathrm{Fe}$ electrodes and $\mathrm{Na}_{2} \mathrm{SO}_{4}$ instead of $\mathrm{KCl}$ as supporting electrolyte. It can be seen that the residual $\mathrm{Pb}$ concentration is brought under the legal limits in 25 minutes of electrolysis time. However, $\mathrm{pH}$ increases only slightly to the value of 4.22 which lies under the lower admissible $\mathrm{pH}$ limit for effluent discharge to the environment. Replacing Fe with $\mathrm{Al}$ electrodes (Fig. 2b) and keeping all other operation parameters unchanged, the residual $\mathrm{Pb}$ concentration is effectively removed in 35 minutes. At the same time $\mathrm{pH}$ reaches the appropriate value of 5.74. Consequently, with $\mathrm{Al}$ electrodes objectives, lead and acidity can simultaneously be removed in a single route. However, the $\mathrm{Pb}$ removal takes some more time.

\subsection{Treatment with a mixture of $\mathrm{Na}_{2} \mathrm{SO}_{4}$ and $\mathrm{KCl}$ as supporting electrolyte}

As the results indicated in sections 3.2 and 3.3 the removal of lead is faster with Fe-electrodes. However, $\mathrm{pH}$ either rises sharply exceeding by far the legal limit or it does not increase sufficiently to the appropriate range, dependent on the existence or absence of chloride respectively. It becomes obvious that a small amount of chloride will lead to a moderate increase of $\mathrm{pH}$, so that also it meets the environmental requirement. For this reason a solution mixture containing $0.03 \mathrm{M} \mathrm{Na}_{2} \mathrm{SO}_{4}$ and only $0.003 \mathrm{M} \mathrm{KCl}$ was chosen as supporting electrolyte and the electrocoagulation treatment of the wastewater was repeated with iron (Fig. 3a) and aluminium (Fig. 3b) electrodes and the same rest operational parameters.

It can be obtained from Fig. 3a that with iron electrodes both, lead and acidity are fast and effectively removed in only 25 minutes of electrolysis time. The residual $\mathrm{Pb}$ concentration of the battery wastewater diminishes under 0.1 $\mathrm{mg} \mathrm{L}^{-1}$ and $\mathrm{pH}$ becomes almost neutral reaching the value of 7.88. When using Al-electrodes and keeping all other parameters unchanged (Fig. $3 b$ ) the residual $\mathrm{Pb}$ concentration diminishes to $0.2 \mathrm{mg} \mathrm{L}^{-1}$ and $\mathrm{pH}$ rises to 8.45 in 35 minutes of electrolysis time. Also here lead and acidity are simultaneously removed. The process, however, is somehow slower.

\subsection{Electrode mass loss and energy consumption}

The costs in wastewater treatment with electrocoagulation are the expenditure on mass loss of electrodes and the electrical energy consumption. The mass loss per liter of the aluminum or iron electrode $m_{E l}$ during the wastewater treatment can be calculated from equation (1) using the Faraday's law:

$$
m E l=\frac{I \cdot t \cdot M}{z \cdot F \cdot V}
$$

where $V=$ volume of treated wastewater (L).

Under the operating conditions given the mass loss of the sacrificial aluminum and iron anode for the electrocoagulation of the wastewater with the mixed $\mathrm{Na}_{2} \mathrm{SO}_{4}$ and $\mathrm{KCl}$ supporting electrolyte solution is $2.176 \theta 10^{-2} \mathrm{~g} \mathrm{Al}$ and $3.218 \theta 10^{-2} \mathrm{~g} \mathrm{Fe}$ per liter of treated wastewater respectively.

Similarly, the electrical energy consumption $E$ is calculated from equation (2):

$$
E=\frac{U \cdot I \cdot t}{V}
$$


where $U=$ applied voltage (Volts).

Correspondingly, the energy consumption for aluminum and iron electrocoagulation with the mixed $\mathrm{Na}_{2} \mathrm{SO}_{4}$ and $\mathrm{KCl}$ supporting electrolyte solution amounts to 0.534 and 0.382 Wh per liter of treated wastewater.

\subsection{Sludge characteristics}

The precipitated sludge was collected, dried at $103^{\circ} \mathrm{C}$ for $24 \mathrm{~h}$, cooled in a desiccator and weighed. Its amount is determined by the Faraday's law. The electrocoagulation treatment produces apparently lower amounts of sludge compared to the conventional chemical precipitation coagulation processes.

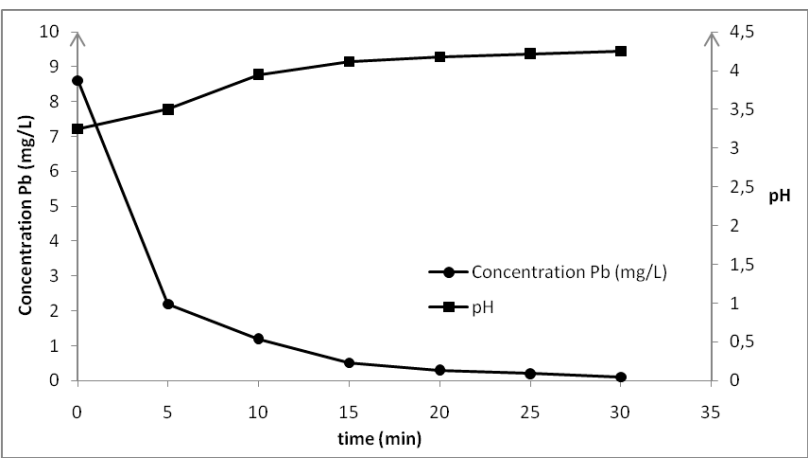

(a)

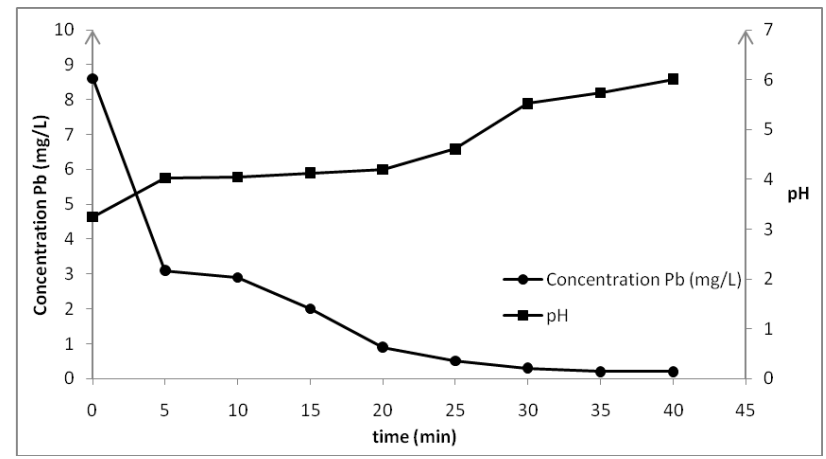

(b)

Fig. 2. Residual $\mathrm{Pb}^{2+}$ ion concentration and $\mathrm{pH}$ variation versus time during electrocoagulation of acid battery wastewater with a) iron electrodes and b) aluminum electrodes. (supporting electrolyte $\mathrm{Na}_{2} \mathrm{SO}_{4}$ $0.03 \mathrm{M}$, solution volume $\mathrm{V}=250 \mathrm{ml}$, current density $\mathrm{i}=10 \mathrm{~mA} \mathrm{~cm}{ }^{2}$ ).

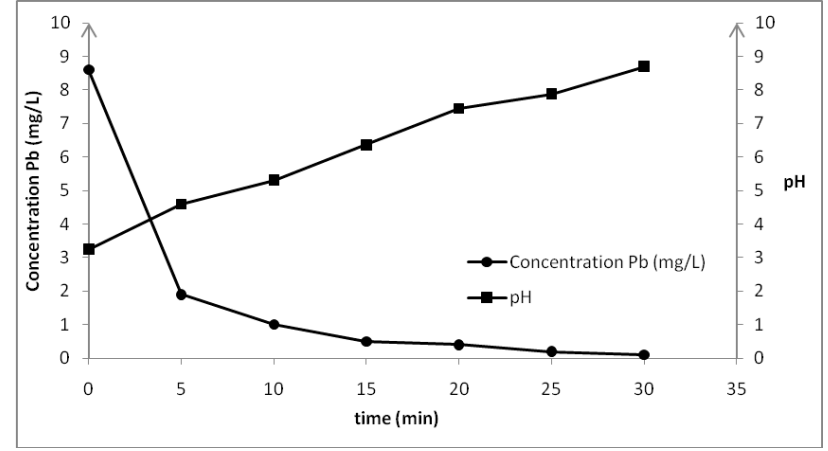

(a)

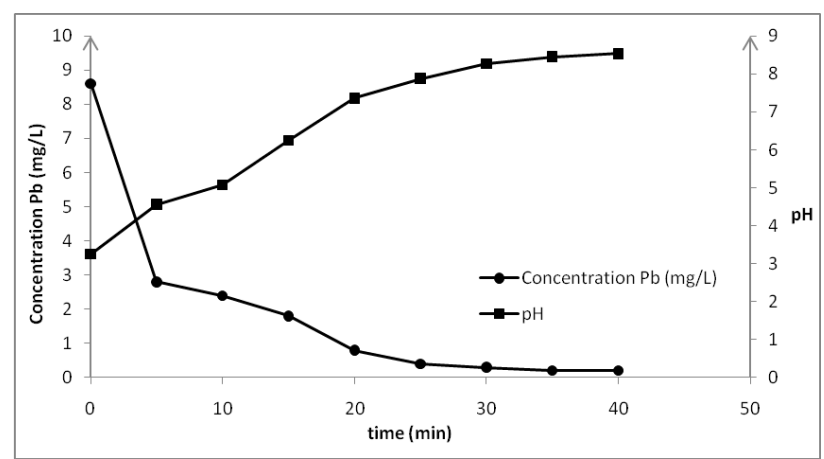

(b)

Fig. 3. Residual $\mathrm{Pb}^{2+}$ ion concentration and $\mathrm{pH}$ variation versus time during electrocoagulation of acid battery wastewater with a) iron electrodes and b) aluminum electrodes. (supporting electrolyte $\mathrm{Na}_{2} \mathrm{SO}_{4}$ $0.03 \mathrm{M}+\mathrm{KCl} 0.003 \mathrm{M}$, solution volume $\mathrm{V}=250 \mathrm{ml}$, current density $\mathrm{i}=10 \mathrm{~mA} \mathrm{~cm}{ }^{2}$ ).

\section{Conclusions}

In this study the applicability of electrocoagulation in the treatment of acid battery manufacturing wastewater for simultaneous removal of both, lead and acidity was investigated. Iron and aluminium sacrificial electrodes and $\mathrm{Na}_{2} \mathrm{SO}_{4}, \mathrm{KCl}$ and a mixture of them as supporting electrolytes were tested and their efficiencies compared. Iron electrodes cause faster removal of lead than aluminium electrodes. Using $\mathrm{KCl}$ as supporting electrolyte $\mathrm{pH}$ increases sharply exceeding the upper legal limit for effluent discharge to the environment. On the contrary, by replacing $\mathrm{KCl}$ with $\mathrm{Na}_{2} \mathrm{SO}_{4}$, pH does not increase sufficiently to the permissible range. It was found that best removal efficiency for both, lead and acidity is achieved by using a mixed supporting electrolyte solution containing $0.03 \mathrm{M} \mathrm{Na}_{2} \mathrm{SO}_{4}$ and $0.003 \mathrm{M}$ $\mathrm{KCl}$.

\section{References}

1. G. Macchi, M. Pagano, M. Santori, G. Tiravanti, Water Res., 27, 1511 (1993).

2. T. Bahadir, G. Bakan, L. Atlas H. Buyukgungor, Enz. Microb. Technol., 41, 98 (2007).

3. K.M. Ibrahim, T. Akashah, Environm. Geology, 46, 865 (2004).

4. K. Basta, A Aliane, A. Lounis, R. Sandreaux, J. Sandreaux, C. Gavach, Desalination, 120, 175 (1998).

5. K. Dermentzis, Electrochim. Acta, 53, 2953 (2008).

6. K.I. Dermentzis, A.E. Davidis, C.D. Chatzichristou, Water Sci. Technol., 62, 1947 (2010).

7. M. Kobya, O.T. Can, M. Bayramoglu, J. Hazard. Mater., B100, 163 (2003).

8. I. Kabdasli, B. Vardar, I. Arslan-Alaton, O. Tünay, Chem. Engin. J., 148, 89 (2009).
9. O.Abdelwahab, N.K. Amin, E-S.Z. El-Ashtoukhy, J. Hazard. Mater., 163, 711 (2009).

10. U.T. Un, A.S. Koparal, U.B. Ogutveren., J. Environm. Manag., 90, 428 (2009).

11. S. Tchamango, C.P. Nanseu-Njiki, E. Ngameni, D. Hadjiev, A. Darchen, Sci. Total Environm., 408, 947 (2010).

12. O. Chavalparit, M. Ongwandee, , J. Environm. Sci, 21, 1491 (2009).

13. M.H. El-Naas, S. Al-Zuhair, A. Al-Lobaney, S. Makhlouf, J. Environm. Manag., 91, 180 (2009).

14. Chin-Ta Wang, Wei-Lung Chou, Yi-Ming Kuo, J. Hazard. Mater., 164, 81 (2009).

15. M. Asselin, P. Drogui, H. Benmoussa, J-F. Blais, Chemosphere, 72, 1727 (2008) 
K. Dermentzis, E. Valsamidou, D. Marmanis /Journal of Engineering Science and Technology Review 5 (2) (2012) 1-5

16. H.K. Hansen, P. Nunez, D. Raboy, I. Schippacase, R. Grandon, Electrochim. Acta, 52, 3464 (2007).

17. C-Y. Hu, S-L. Lo, W.H. Kuan, Y.D. Lee, Sep. Purif. Technol., 60, 1 (2008).

18. F. Akbal, S. Camci, Chem. Engin. Technol., 33, 1655 (2010).

19. J. Nouri, A.H. Mahvi, E. Bazrafshan, Intern. J. Environm. Res., 4, 201 (2010).
20. K. Dermentzis, A. Christoforidis, E. Valsamidou, Intern. J. Environm. Sci. 1, 697 (2011).

21. I. Kabdasli, T. Arslan, T.Ölmez-Hanci, I. Arslan-Alaton, O. Tünay, J. Hazard. Mater. 165, 838 (2009).

22. P. Suwanvitaya, P. Suwanvitaya, V. Mutiisan, PMC2000 Paper Template, RSID6-STR-39. 